\title{
Drying kinetics of fermented grape pomace: Determination of moisture effective diffusivity
}

\author{
Kricelle M. Deamici ${ }^{1}$, Lucas C. de Oliveira ${ }^{2}$, Gabriela S. da Rosa ${ }^{3}$ \& Elizangela G. de Oliveira ${ }^{4}$ \\ ${ }^{1}$ Universidade Federal do Rio Grande/Escola de Química e Alimentos/Laboratório de Engenharia Bioquímica. Rio Grande, RS.E-mail:kricelledeamici@gmail.com \\ ${ }^{2}$ Universidade Federal do Pampa/Campus Bagé/Engenharia de Alimentos. Bagé, RS. E-mail: lucas_carvalho33@yahoo.com.br \\ ${ }^{3}$ Universidade Federal do Pampa/Campus Bagé/Engenharia Química. Bagé, RS. E-mail: gabrielarosa@unipampa.edu.br \\ ${ }^{4}$ Universidade Federal do Rio Grande do Sul/Instituto de Ciência e Tecnologia de Alimentos/Departamento de Tecnologia de Alimentos. Porto Alegre, RS. \\ E-mail: elizangela.oliveira@ufrgs.br (Corresponding author)
}

\section{Key words:}

byproducts

isotherms

proteins

fibers

\begin{abstract}
A B S T R A C T
The aim of this study was to obtain the equilibrium moisture content of grape (variety 'Tannat') pomace through desorption isotherms, to evaluate the drying kinetics, determine the coefficient of effective diffusivity and physico-chemically characterize the grape pomace and the product obtained after drying. The desorption isotherms were determined at 50 , 60 and $70^{\circ} \mathrm{C}$ and the experimental data were fitted using the GAB model (Gugghenheim, Anderson and de Boer). Drying was evaluated using a $2^{2}$ factorial experimental design with three center points and effective diffusivity was obtained through the diffusion model of Fick's second law. The grape pomace was characterized regarding the contents of moisture, protein, carbohydrates, lipids, ash and dietary crude fiber. The obtained isotherms showed sigmoid shape and the experimental data fitted well to the GAB model. The drying curves showed only a decreasing rate period. The effective diffusivity values were within the range for organic materials. Dry grape pomace showed high contents of protein and fiber and can be used in the development of new products, in order to increase the nutritional content and add value to this byproduct.
\end{abstract}

\section{Palavras-chave: subprodutos isotermas proteínas fibras}

\section{Cinética de secagem do bagaço de uva fermentado: Determinação da difusividade efetiva de umidade}

\begin{abstract}
R E S U M O
Propôs-se, neste trabalho, obter a umidade de equilíbrio do bagaço de uva da variedade Tannat por meio das isotermas de dessorção e avaliar a cinética de secagem, além de determinar o coeficiente de difusividade efetiva e caracterizar, físico-quimicamente, o bagaço de uva e o produto obtido pós-secagem. As isotermas de dessorção foram determinadas a 50, 60 e $70{ }^{\circ} \mathrm{C}$ e os dados experimentais foram ajustados pelo modelo de GAB (Gugghenheim, Anderson e de Boer). A secagem foi avaliada por meio de um planejamento experimental fatorial $2^{2} \mathrm{com}$ três pontos centrais enquanto a difusividade efetiva foi obtida através do modelo difusivo da segunda Lei de Fick. O bagaço de uva foi caracterizado quanto ao teor de água, proteínas, carboidratos, lipídeos, cinzas e fibra bruta alimentar. As isotermas obtidas apresentaram formato sigmoidal e os dados experimentais se ajustaram bem ao modelo de GAB; as curvas de secagem apresentaram apenas o período de taxa decrescente; os valores da difusividade efetiva se mantiveram dentro da faixa para materiais orgânicos; já o bagaço de uva seco apresentou elevado teor de proteínas e fibras podendo ser inserido no desenvolvimento de novos produtos a fim de elevar o teor nutricional e agregar valor a este subproduto.
\end{abstract}




\section{INTRODUCTION}

The generation of residues in wine production is approximately $18 \mathrm{~kg}$ of grape pomace for every $100 \mathrm{~L}$ of wine (Rockenbach et al., 2011), whose main destination is animal feed and composting. These residues may become byproducts and receive adequate treatment, generating new products or enriching already existing products, since the byproducts of grape processing contain substances of economic interest, such as phenolic compounds and fibers. The use of this residue as byproduct can also represent significant economic gains and prevent or decrease environmental problems caused by the accumulation of the generated grape pomace (Campos et al., 2008).

One of the alternatives for grape pomace as food is the use of the dry pomace, which can be obtained from the drying operation, one of the most usual operations in chemical and food industries with respect to the conservation of the products. According to Ullmann et al. (2010), this operation reduces the amount of water in the product, in order to inhibit biological activity and chemical and physical changes that occur during the storage.

Based on the importance of the knowledge on the stability of products subjected to drying and the presence of various wineries in the state of Rio Grande do Sul, which generate large amounts of fermented grape pomace, from the processing of wine, it becomes necessary to study the reuse of this dry byproduct, in order to add nutritional value to the foods intended for human consumption. In this context, this study aimed to determine the equilibrium moisture of 'Tannat' grape pomace through desorption isotherms, evaluate its drying kinetics, determine the effective diffusivity coefficient $\left(D_{\text {ef }}\right)$ and physico-chemically characterize the grape pomace and the product obtained after drying, for probable use in the preparation of new food products.

\section{Material AND Methods}

The present study used, as raw material, fermented pomace of grapes, variety 'Tannat', from the 2011/2012 season (single lot), provided by a winery located in the city of Bagé, RS. In order to maintain the uniformity, after the samples received, the grape pomace was stored in plastic bags at temperature of $-18{ }^{\circ} \mathrm{C}$ until the analysis and experiment. This study was carried out from March to May 2013 at the Laboratories of Food Engineering and Chemical Engineering of the Federal University of Pampa.

The desorption isotherms of grape pomace were performed through the static gravimetric method, with acid solutions at eleven different concentrations. Glass containers (diameter of $6 \mathrm{~cm}$ and height of $8 \mathrm{~cm}$ ), hermetically closed, were used to guarantee a constant atmosphere. Inside the containers, besides the plastic support for the sample, there were sulfuric acid solutions varying from 0.20 to $0.70 \mathrm{~kg} \mathrm{~kg}^{-1}$, which guaranteed the variation of relative air humidity in the range of 5 to $89 \%$ inside the experimental apparatus. Each concentration of acid solution was used in triplicate and the procedure consisted in the weighing of approximately $1 \mathrm{~g}$ of sample (fresh grape pomace), which was placed in the container inside the glass jar so that the acid solution did not come into contact with the sample. The containers were stored in a forced-air oven (Nova Ética, model 400-5 ND, Brazil) at the studied temperatures (50, 60 and $70^{\circ} \mathrm{C}$ ). In regular time intervals, the containers with the samples were weighed on an analytical scale with precision of $\pm 0.001 \mathrm{~g}$ (Shimadzu, model AUY220, Japan) until the period necessary to reach equilibrium (constant mass). As the equilibrium condition was achieved, the moisture analysis was performed in an oven, through the static gravimetric method $\left(105^{\circ} \mathrm{C}\right.$ for $24 \mathrm{~h}$ ) following the methodology of the Association of Official Analytical Chemists (AOAC, 1997).

For the fitting of the experimental data of the desorption isotherms, the GAB (Gugghenheim, Anderson and Boer) equation (Eq. 1) was applied, using a nonlinear regression, through the Quasi-Newton method; only in this way it was possible to obtain the values of monolayer moisture content $\left(\mathrm{X}_{\mathrm{m}}\right)$ and the parameters of model.

$$
\mathrm{X}_{\mathrm{eq}}=\frac{\mathrm{X}_{\mathrm{m}} \cdot \mathrm{C} \cdot \mathrm{k} \cdot \mathrm{RH}}{(1-\mathrm{k} \cdot \mathrm{RH})(1-\mathrm{k} \cdot \mathrm{RH}+\mathrm{c} \cdot \mathrm{K} \cdot \mathrm{RH})}
$$

where:

$X_{\text {eq }}$ - equilibrium moisture content, $\mathrm{kg} \mathrm{kg}^{-1}$;

$\mathrm{X}_{\mathrm{m}}$ - monolayer moisture content;

$\mathrm{k}$ and $\mathrm{C}$ - model constants; and,

$\mathrm{RH}$ - relative humidity.

The quality of the experimental data fit to the GAB model was evaluated based on the coefficient of determination $\left(R^{2}\right)$ and on the low value of the mean relative error (MRE), obtained using Eq.2.

$$
\mathrm{MRE}=\frac{100}{\mathrm{n}} \sum_{\mathrm{i}=1}^{\mathrm{n}} \frac{\left|\mathrm{Xe}_{\mathrm{Exp}}-\mathrm{Xe}_{\mathrm{Pr} \mathrm{e}}\right|}{\mathrm{Xe}_{\mathrm{Exp}}}
$$

where:

$\mathrm{Xe}_{\text {Exp }}$ - equilibrium moisture obtained experimentally;

$\mathrm{Xe}_{\text {pre }}$ - equilibrium moisture predicted by the model; and,

$n$ - number of experimental observations.

The drying kinetics of the fresh grape pomace was studied using a parallel-flow tray dryer (ECO Educacional, Brazil), shown in Figure 1.

For the drying, the initial mass of solids was approximately of $50 \mathrm{~g}$, placed on a tray with diameter of $16 \mathrm{~cm}$. The pomace mass was weighed every $2 \mathrm{~min}$ (until the time of $30 \mathrm{~min}$ ); subsequently, weighing was performed every 5 min (until the time of $100 \mathrm{~min}$ ) and then every $10 \mathrm{~min}$ until the system reached mass equilibrium. Weighing was performed in the dryer, on a scale attached to the system. The electric panel displayed dry bulb (DBT) and wet bulb (WBT) temperatures of the air at the inlet, the temperature of the drying air $(\mathrm{T})$, air speed inside the dryer (v) and the mass of solids on the tray $(\mathrm{g})$.

The $2^{2}$ factorial planning with three center points was used to evaluate the drying kinetics of 'Tannat' grape pomace. The utilized levels and the corresponding values are presented in Table 1. 


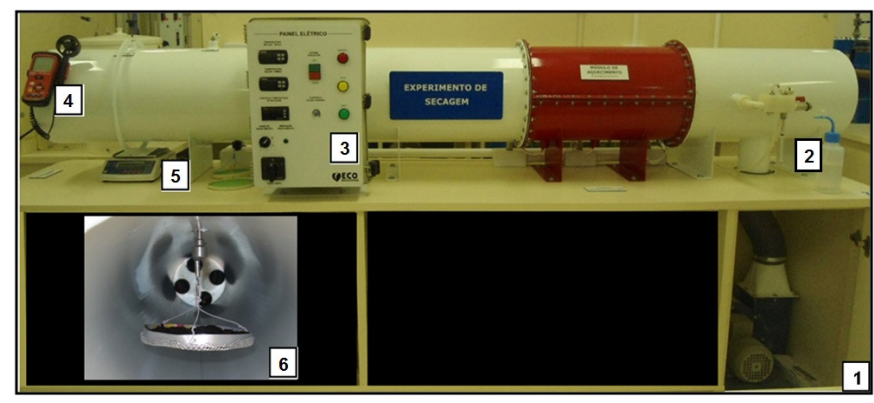

(1) Blower sends air to the device; (2) psychrometer reads inlet air conditions; (3) electric panel that informs drying temperature, dry bulb temperature and wet bulb temperature and controls the drying air speed; (4) anemometer that checks air speed; (5) scale attached to the dryer constantly monitoring sample mass; (6) sample placed on a metal tray with perforated bottom inside the tunnel

Figure 1. Fixed-bed dryer with parallel air flow used in the study of drying kinetics

Table 1. Planning used for the drying tests

\begin{tabular}{ccc}
\hline \multirow{2}{*}{ Test } & \multicolumn{2}{c}{ Dependent variables } \\
\cline { 2 - 3 } 1 & $\mathbf{T}\left({ }^{\circ} \mathbf{C}\right)$ & $\mathbf{v}\left(\mathbf{m ~ s}^{-1}\right)$ \\
2 & 50 & 1 \\
3 & 70 & 1 \\
4 & 50 & 2 \\
5 & 70 & 2 \\
6 & 60 & 1.5 \\
7 & 60 & 1.5 \\
\hline
\end{tabular}

After each test, it was possible to obtain the absolute humidity $(\mathrm{AH})$, relative humidity $(\mathrm{RH})$ of the drying air and the equilibrium moisture content $\left(\mathrm{X}_{\mathrm{e}}\right)$ for each experimental condition of drying. The curves of characterization of drying were obtained from the dimensionless content of free water $\left(\mathrm{X}-\mathrm{X}_{\mathrm{e}}\right) /\left(\mathrm{X}_{0}-\mathrm{X}_{\mathrm{e}}\right)$ as a function of the drying time (min) until obtaining mass equilibrium.

The effective diffusivity $\left(\mathrm{D}_{\mathrm{ef}}\right)$ was determined using the diffusion model of the Fick's Law of thin-layer drying, as presented in Eq. 3.

$$
\frac{X-X_{e}}{X_{0}-X_{e}}=\frac{8}{\pi^{2}} \exp ^{\left[-\left(\frac{\pi}{L_{o}}\right)^{2} D_{e f} \cdot t\right]}
$$

where:

$\mathrm{X}$ - mean moisture content at time $\mathrm{t}\left(\mathrm{kg} \mathrm{kg}^{-1}\right)$;

$\mathrm{X}_{\mathrm{e}} \quad$ - equilibrium moisture content of the product $\left(\mathrm{kg} \mathrm{kg}^{-1}\right)$;

$\mathrm{X}_{0}$ - moisture content at the initial time $\left(\mathrm{kg} \mathrm{kg}^{-1}\right)$;

$\mathrm{L}_{0} \quad$ - thickness of the layer of solids on the tray $(\mathrm{m})$; and,

t $\quad$ - time (s).

The physico-chemical analysis were performed in the fresh grape pomace and in the pomace after drying, under the condition of $70^{\circ} \mathrm{C}$ and $1 \mathrm{~m} \mathrm{~s}^{-1}$. This condition was selected due to the satisfactory time to reach mass equilibrium, besides being possible to use ovens for the drying in larger proportions. All analysis were performed in triplicate. The samples were characterized with respect to the contents of moisture, proteins, lipids, ashes and dietary fiber, determined according to the methodology described by the Association of Official Analytical Chemists (AOAC, 1997), and the Adolfo Lutz Institute - IAL (2008). The moisture content was obtained in an oven with cross air circulation at $105^{\circ} \mathrm{C}$ for $24 \mathrm{~h}$. The protein content present in the samples was determined by the Kjeldahl method. The lipid content was determined in a rotary Soxhlet extractor, using petroleum ether as the solvent. The amount of ashes was determined with the use of an incinerator (muffle furnace) at temperature of $550{ }^{\circ} \mathrm{C}$ until the samples reached constant weight. The content of carbohydrates was obtained by difference.

Crude fiber (CF) was analyzed through the method proposed by Rodrigues (2010), using degreased samples and its content in the samples was obtained according to Eq. 4.

$$
\% \mathrm{CF}=\frac{(\mathrm{CM}+\% \mathrm{CF})-(\mathrm{CM}+\% \mathrm{~A}) \cdot 100}{\mathrm{SM} \cdot \% \operatorname{MDS}\left(105{ }^{\circ} \mathrm{C}\right)}
$$

where:

CM - crucible mass;

A - ash obtained after incineration;

SM - sample mass; and,

MDS - mass of the sample dried at $105^{\circ} \mathrm{C}$.

\section{Results AND Discussion}

Figure 2 shows the desorption isotherms of fresh grape pomace at the temperatures of 50,60 and $70{ }^{\circ} \mathrm{C}$, obtained from the experimental values of equilibrium moisture content $\left(\mathrm{X}_{\mathrm{e}}\right)$ and relative humidity $(\mathrm{RH})$. The obtained curves (Figure 2) show a sigmoid shape, characteristic of the type-II curve, according to the classification of Brunauer et al. (1938), who consider the sigmoid shape of the hygroscopic equilibrium a standard for organic products.

Table 2 presents the values of the parameters calculated from the fit of the GAB equation data (Eq. 1) with their respective coefficients of determination $\left(\mathrm{R}^{2}\right)$ and relative mean errors (RME).

According to Table 2, all obtained values of $\mathrm{R}^{2}$ remained above 0.97 , with RME below $10 \%$, which represents a good fit of the GAB model, according to Mohapatra \& Rao (2005). For the values of GAB model parameters, the increment in temperature leads to a decrease in the moisture content of the molecular monolayer $\left(\mathrm{X}_{\mathrm{m}}\right)$. The same phenomenon was observed by Al-Muhtaseb et al. (2004), who evaluated

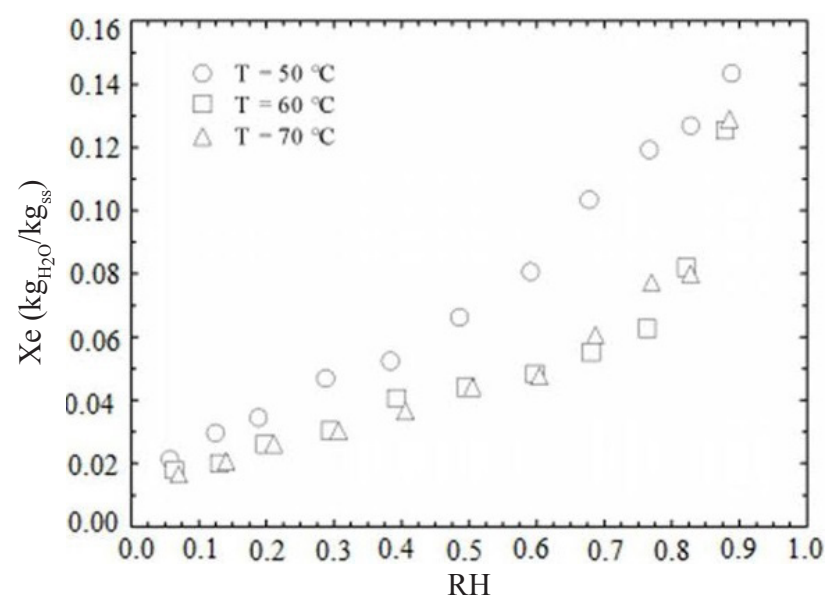

Figure 2 . Desorption isotherms of 'Tannat' grape pomace at 50,60 and $70{ }^{\circ} \mathrm{C}$ 
Table 2. Values of the parameters obtained from the fit of the GAB model for grape pomace at the studied temperatures

\begin{tabular}{clcc}
\hline $\begin{array}{c}\text { Temperature } \\
\left({ }^{\circ} \mathbf{C}\right)\end{array}$ & Values of GAB model parameters & $\mathbf{R}^{2}$ & $\begin{array}{c}\text { RME } \\
(\%)\end{array}$ \\
50 & $\mathrm{X}_{\mathrm{m}}=0.05 ; \mathrm{C}=9.52 ; \mathrm{k}=0.75$ & 0.99 & 6.45 \\
60 & $\mathrm{X}_{\mathrm{m}}=0.02 ; \mathrm{C}=77.39 ; \mathrm{k}=0.93$ & 0.97 & 9.65 \\
70 & $\mathrm{X}_{\mathrm{m}}=0.02 ; \mathrm{C}=45.16 ; \mathrm{k}=0.92$ & 0.98 & 8.57 \\
\hline
\end{tabular}

desorption isotherms in starch powders, and McLaughlin \& Magee (1998), who used potatoes and claimed that this trend can be explained by the variation in the state of agitation, distance and attraction between water molecules with the variation in temperature, since it is a parameter of fundamental importance and the $\mathrm{X}_{\mathrm{m}}$ value determines the moisture content that is absorbed from the foods, allowing higher stability of the studied material. The parameters $\mathrm{k}$ and $\mathrm{C}$ are constants of adsorption related to energetic interactions between the monolayer molecules and the subsequent ones, on a sorption site (Park et al., 2008). The values of these constants are an indication about the corresponding type of isotherm, according to the classification of Brunauer et al. (1938). Values of $\mathrm{k}<1$ and $\mathrm{C}>2$ are considered as type-II isotherms (Paglarini et al., 2013), a fact confirmed by the graphs shown in Figure 2.

Table 3 shows air temperatures of inlet (DBT) and drying (WBT) of the tests of the experimental planning. With the aid of a psychrometric chart, it was possible to characterize the drying air with respect to the absolute humidity $(\mathrm{AH})$ and relative air humidity $(\mathrm{RH})$. Later, using the values of the GAB model parameters and the $\mathrm{RH}$ at each drying temperature, it was possible to obtain the values of equilibrium moisture content of the material for each studied test.

Park et al. (2007) reported that RH can be considered as the relationship between the mass of water vapor and the mass of dry air in the same volume of mixture, while AH is the relationship between the molar fraction of the water vapor in the mixture and the fraction of water vapor in a saturated mixture at the same pressure and temperature. Hence, the results in Table 3 are consistent, since as temperature increased, $\mathrm{RH}$ become lower, because the driving force contributes for the drying process to occur efficiently. Therefore, as temperature increased, the removal of water from 'Tannat' grape pomace was more effective.

The drying kinetics of grape pomace was characterized by the curves presented in Figure 3.

According to Figure 3, it is possible to observe that there was no representativeness of the constant rate period for any of

Table 3. Drying air data for each test, obtained from the psychrometric chart

\begin{tabular}{|c|c|c|c|c|c|}
\hline \multirow{2}{*}{ Test } & DBT & WBT & \multirow{2}{*}{$\begin{array}{c}\mathrm{AH} \\
\left(\mathrm{kg}_{\text {water }} \mathrm{kg}_{\text {dryair }}{ }^{-1}\right)\end{array}$} & \multirow{2}{*}{$\begin{array}{l}\text { RH } \\
(\%)\end{array}$} & \multirow{2}{*}{$\begin{array}{c}\mathrm{Xe} \\
\left(\mathrm{kg}_{\text {water }} \mathrm{kg}_{\text {drysolid }}{ }^{-1}\right)\end{array}$} \\
\hline & \multicolumn{2}{|c|}{$\left({ }^{\circ} \mathrm{C}\right)$} & & & \\
\hline 1 & 20.9 & 18.8 & 0.01 & 16.42 & 0.06 \\
\hline 2 & 22.2 & 20.1 & 0.01 & 7.03 & 0.02 \\
\hline 3 & 22.9 & 19.9 & 0.01 & 17.23 & 0.06 \\
\hline 4 & 24.9 & 21.7 & 0.01 & 7.72 & 0.03 \\
\hline 5 & 22.0 & 18.2 & 0.01 & 10.74 & 0.05 \\
\hline 6 & 22.5 & 18.8 & 0.01 & 9.67 & 0.05 \\
\hline 7 & 26.1 & 20.2 & 0.01 & 10.70 & 0.05 \\
\hline
\end{tabular}

DBT - Dry bulb temperature; WBT - Wet bulb temperature; AH - Air humidity; RH - Relative humidity, Xe - Equilibrium moisture content of the product

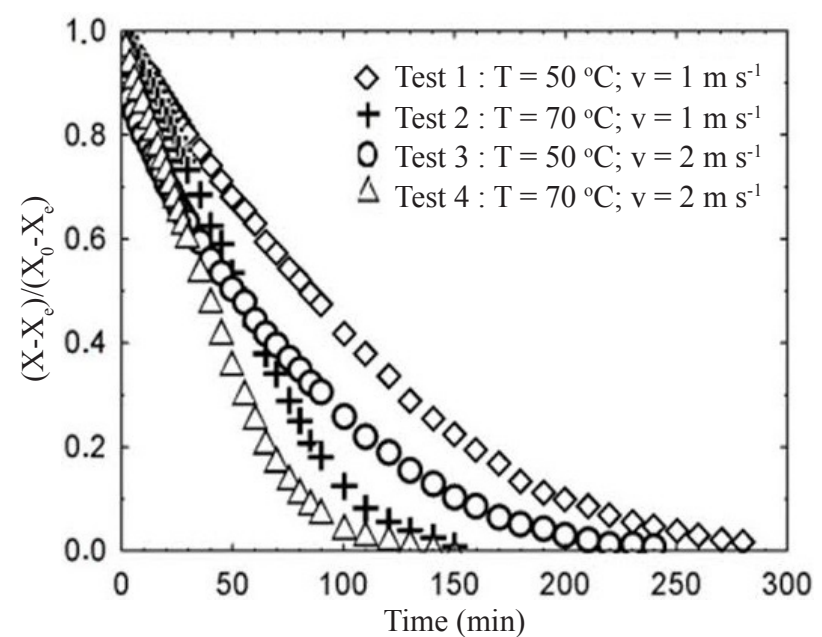

Figure 3. Curves of the drying kinetics of 'Tannat' grape pomace without the representation of the central point

the studied curves, which was also observed by Ferreira et al. (2012), who did not find constant rate period for the study of the mathematical modeling of thin-layer drying of fermented grape pomace for the studied temperatures of 50,60, 70, 80 and $90{ }^{\circ} \mathrm{C}$. Therefore, the entire process occurred in a decreasing rate, a result also reported by Doymaz (2008) and Menezes et al. (2013), for the study of drying of strawberry and yellow passion fruit pomace, respectively. From this point on, it is observed that, without the constant rate period, the diffusion becomes the dominant physical mechanism that drives the transfer of mass in the form of moisture from the material to the drying air. The values of moisture content obtained at the end of the experiments (mass equilibrium) ranged from 0.12 to $0.19 \mathrm{~kg} \mathrm{~kg}^{-1}$. The fact that the drying only occurred in the decreasing rate can be explained, because organic products are considered as hygroscopic, since the part of the moisture present in the material is found in proteins, carbohydrates and colloidal substances in the form of solutions (Park et al., 2007). Table 4 presents the results fitted to the mathematical model of the Fick's Law for the seven drying tests along with the values of $R^{2}$ and $D_{\text {ef }}$

The values of effective diffusivity for each drying test demonstrate that, with the increase in temperature and air flow speed, there is an increment in the value of effective diffusivity. According to Madamba (2003), this phenomenon occurs because the effective diffusivity represents the speed with which the water migrates from the inside to the surface of the material, then being vaporized. Therefore, the higher the energy supplied by the system, the higher will also be the increase in water evaporation and the lower the internal

Table 4. Observed values of effective diffusivity (Def) for the drying condition analyzed by the Fick's Law model

\begin{tabular}{ccc}
\hline Tests & $\mathbf{D}_{\text {ef }}\left(\mathbf{m}^{2} \mathbf{s}^{-1}\right)$ & $\mathbf{R}^{\mathbf{2}}$ \\
1 & $2.68 \times 10^{-11}$ & 0.970 \\
2 & $4.51 \times 10^{-11}$ & 0.960 \\
3 & $3.77 \times 10^{-11}$ & 0.980 \\
4 & $6.60 \times 10^{-11}$ & 0.970 \\
5 & $5.79 \times 10^{-11}$ & 0.980 \\
6 & $5.59 \times 10^{-11}$ & 0.980 \\
7 & $4.65 \times 10^{-11}$ & 0.979 \\
\hline
\end{tabular}


resistances of drying. The author also reports that the values of effective diffusivity for organic materials are between $10^{-11}$ and $10^{-9} \mathrm{~m}^{2} \mathrm{~s}^{-1}$. In the present study, the observed values of effective diffusivity are within this range, presented by Madamba (2003). After the study of drying, the grape pomace obtained after drying under the condition proposed in the test $2\left(70{ }^{\circ} \mathrm{C}\right.$ and $1 \mathrm{~m} \mathrm{~s}^{-1}$ ) was subjected to physico-chemical characterization.

Table 5 shows the physico-chemical characterization of the fresh grape pomace and dried grape pomace under conditions of $70^{\circ} \mathrm{C}$ and $1 \mathrm{~m} \mathrm{~s}^{-1}$ regarding the contents of moisture, proteins, ashes, lipids, carbohydrates and fibers.

The content of proteins of the grape pomace flour was close to that reported in the study of Ferreira (2010), who observed

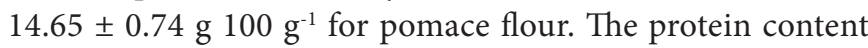
of the grape is dependent on the cultivar and the proteins are mainly present in its pulp, which is not part of the pomace. During the production of wine, the content of soluble proteins decreases in the grape pomace due to the pressing stage and, at the end of the fermentation, many proteins precipitate with the tannins (Jackson, 2008). The content of carbohydrates observed in the flour of 'Tannat' grape pomace was lower than

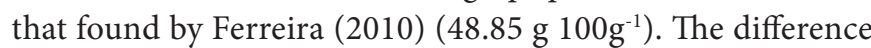
in the content of carbohydrates is justified by the fact that this nutrient is related to the maturation stage with which the fruits are harvested, climate, soil, cultural tracts and processing to which the grape will be subjected, since, in the production of red wine, the fermentable sugars are transformed into alcohol and will not be available in the pomace.

The content of crude fiber was similar to that obtained in the study of Baumgãrtel et al. (2007) (31.20\%). The value obtained by Ferreira (2010) was lower than that found in the

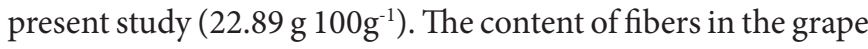
pomace may be higher than the observed one, since the content of crude fiber represents only one portion of the insoluble fibers, assuming that the observed value is underestimated for the total content of dietary fiber of the grape pomace (Salgado et al., 1999). According to the National Health Surveillance Agency (ANVISA), for labeling purposes, the food is considered as with high fiber content when it has minimum value of $6 \mathrm{~g}$ of fibers per $100 \mathrm{~g}$ of the solid product (ANVISA, 2012). Therefore, the byproduct treated through drying can be considered as a product with high content of fibers.

Piovesana et al. (2013) evaluated the partial substitution of wheat flour by flour of grape pomace and oat in the elaboration of cookies and the results demonstrated that the cookies showed acceptable sensorial properties, with good acceptability by the judges. In the present study, the drying operation under

Table 5. Physicochemical characterization of fresh grape pomace and grape pomace after drying (wet basis)

\begin{tabular}{|c|c|c|}
\hline \multirow{2}{*}{$\begin{array}{c}\text { Physicochemical } \\
\text { analysis }\end{array}$} & Fresh grape pomace & Grape pomace after drying \\
\hline & \multicolumn{2}{|c|}{$\left(\% \mathrm{~m} \mathrm{~m}^{-1}\right)^{\star}$} \\
\hline Moisture & $63.61 \pm 2.07$ & $8.30 \pm 0.08$ \\
\hline Proteins & $6.28 \pm 2.04$ & $12.10 \pm 0.91$ \\
\hline Ashes & $5.06 \pm 0.26$ & $9.09 \pm 0.35$ \\
\hline Lipids & $1.87 \pm 0.02$ & $5.87 \pm 0.20$ \\
\hline Carbohydrates & $4.81 \pm 1.02$ & $29.24 \pm 0.60$ \\
\hline Fibers & $18.37 \pm 1.87$ & $35.40 \pm 1.54$ \\
\hline
\end{tabular}

*Mean values \pm mean deviation (triplicate) the studied conditions allowed a viable alternative for the destination of the grape pomace generated in wine industries. As already presented, it is possible to use dry grape pomace in new products or in already existing products, in order to add value to this byproduct, increasing the nutritional content of the new product developed.

\section{Conclusions}

1. The desorption isotherms of 'Tannat' grape pomace show a sigmoid shape, type II, typical of agricultural products. The equilibrium moisture contents obtained with the fit of the GAB model varied between 0.02 and $0.06 \mathrm{~kg}_{\text {water }} \mathrm{kg}_{\text {drysolid }}{ }^{-1}$

2. The characteristic drying curves showed only the decreasing rate period. The model that describes the Fick's Law in relation to the utilized data showed values in agreement with values estimated for organic products, comprehended in these $2.68 \times 10^{-11}$ and $6.60 \times 10^{-11} \mathrm{~m}^{2} \mathrm{~s}^{-1}$, for the lowest and highest level used in the experimental planning, respectively.

3. The flour of 'Tannat' grape pomace obtained after drying showed high contents of proteins and fibers, with values of 12.10 and $35.40 \%\left(\mathrm{~m} \mathrm{~m}^{-1}\right)$, respectively.

4. This study allowed a viable alternative for the destination of grape pomace, enabling the preparation of foods from the drying of the pomace, the grape pomace flour. This product can be commercialized in capsules or in bulk and can be used in partial substitution of wheat flour for the preparation of bakery products.

\section{ACKNOWLedgments}

To the Rio Grande do Sul Research Support Foundation (FAPERGS), for granting the scholarship, and to the Peruzzo Winery, for providing the raw material.

\section{Literature Cited}

Al-Muhtaseb, A. H.; Mcminn, W. A. M.; Magee, T. R. A. Water sorption isotherms of starch powders: Part 1: Mathematical description of experimental data. Journal of Food Engineering. v.61, p.297-307. 2004. http://dx.doi.org/10.1016/S0260-8774(03)00133-X

ANVISA - Agência Nacional de Vigilância Sanitária . Resolução - RDC $\mathrm{n}^{\circ}$ 54, de 12 de novembro de 2012. Dispõe sobre o Regulamento Técnico sobre Informação Nutricional Complementar. Diário Oficial da União, Brasília, 2012. http://goo.gl/ZwZJXr

AOAC - Association of Official Analytical Chemists. Official methods of analysis. 16. ed. Washington: AOAC, v.2, 1997. $1115 p$.

Baumgãrtel, T.; Kluth, H.; Epperlein, K.; Rodehutscord, M. A. Note on digestibility and energy value for shep of different grape pomace. Small Ruminant Research, v.67, p.302-306, 2007. http:// dx.doi.org/10.1016/j.smallrumres.2005.11.002

Brunauer, S.; Emmett, P. H.; Teller, E. Adsorption of gases in multimolecular layer. Journal of American Chemistry Society, v.60, p.309-312, 1938. http://dx.doi.org/10.1021/ja01269a023 
Campos, L. M. A. S.; Leimann, F. V.; Pedrosa, R. C.; Ferreira, S. R. S. Free radical scavenging of grape pomace extracts from Cabernet Sauvingnon (Vitis vinifera). Bioresource Technology, v.99, p.84138420, 2008. http://dx.doi.org/10.1016/j.biortech.2008.02.058

Doymaz, I. Convective drying kinetics of strawberry. Chemical Engineering and Processing, v.47, p.914-919, 2008. http://dx.doi. org/10.1016/j.cep.2007.02.003

Ferreira, L. F. D. Obtenção e caracterização de farinhas de bagaço de uva e sua utilização em cereais matinais expandidos. Viçosa: UFV, 2010. 135p. Doctoral Thesis

Ferreira, L. F. D.; Pirozi, M. R.; Ramos, A. M.; Pereira, J. A. M. Modelagem matemática da secagem em camada delgada de bagaço de uva fermentado. Pesquisa Agropecuária Brasileira, v.47, p.855-862, 2012. http://dx.doi.org/10.1590/S0100204X2012000600017

IAL - Instituto Adolfo Lutz. Normas Analíticas; métodos químicos e físicos para a análise de alimentos. 4. ed. São Paulo: Instituto Adolfo Lutz, 2008. 1020p.

Jackson, R. S. Wine Science - Principles and applications. 3. ed. Amsterdam: Elsevier Inc., 2008. 789p.

Madamba, P. S. Thin layer drying models for osmotically pre-dried young coconut. Drying Technology, v.21, p.1759-1780, 2003. http://dx.doi.org/10.1081/DRT-120025507

McLaughlin, C. P.; Magee, T. R. A. The determination of sorption isotherm and isosteric heats of sorption for potatoes. Journal of Food Engineering, v.35, p.267-280, 1998. http://dx.doi. org/10.1016/S0260-8774(98)00025-9

Menezes, M. L. de; Ströher, A. P.; Pereira, N. C.; Barros, S. T. D. de. Análise da cinética e ajustes de modelos matemáticos aos dados de secagem do bagaço do maracujá-amarelo. Engevista, v.15, p.176-186, 2013.

Mohapatra, D.; Rao, P. S. A thin layer drying model of parboiled wheat. Journal of Food Engineering, v.66, p.513-518, 2005. http://dx.doi. org/10.1016/j.jfoodeng.2004.04.023
Paglarini, C. de S.; Silva, F. S. da; Porto, A. G.; Piasson, D.; Santos, P. dos. Histerese das isotermas de sorção da polpa de manga (Mangifera indica L.) variedade manteiga. Revista Brasileira de Engenharia Agrícola e Ambiental, v.17, p.299-305, 2013. http:// dx.doi.org/10.1590/S1415-43662013000300008

Park, K. J.; Antonio, G. C.; Oliveira, R. A. de; Park, K. J. B. Conceitos de processo e equipamentos de secagem. Campinas: UNICAMP, 2007. 121p. http://www.feagri.unicamp.br/ctea/projpesq.html

Park, K. J. B.; Park, K. J.; Cornejo, F. E. P.; Dal Fabbro, I. M. Considerações termodinâmicas das isotermas. Revista Brasileira de Produtos Agroindústrias, v.10, p.83-94, 2008. http://dx.doi. org/10.15871/1517-8595/rbpa.v10n1p83-94

Piovesana, A.; Bueno, M. M.; Klajn, V. M. Elaboração e aceitabilidade de biscoistos enriquecidos com aveia e farinha de bagaço de uva. Brazilian Journal of Food Technology, v.16, p.68-72, 2013. http:// dx.doi.org/10.1590/S1981-67232013005000007

Rockenbach, I. I.; Rodrigues, E.; Gonzaga, L. V.; Caliari, V.; Genovese, M. I.; Gonçalves, A. E. S. S.; Fett, R. Phenolic compounds content and antioxidant activity in pomace from selected red grapes (Vitis vinifera L. and Vitis labrusca L.) widely produced in Brazil. Food Chemistry, v.127, p.174-179, 2011. http://dx.doi.org/10.1016/j. foodchem.2010.12.137

Rodrigues, R. C. Métodos de análises bromatológicas de alimentos: Métodos físicos, químicos e bromatológicos. Pelotas: Embrapa Clima Temperado, 2010. p.47-51.

Salgado, S. M.; Guerra, N. B.; Melo Filho, A. B. Polpa de fruta congelada: Efeito do processamento sobre o conteúdo de fibra alimentar. Revista de Nutrição, v.12, p.303-308, 1999. http:// dx.doi.org/10.1590/S1415-52731999000300009

Ullmann, R.; Resende, O.; Sales, J. de F.; Chaves, T. H. Qualidade das sementes de pinhão manso submetidas à secagem artificial. Revista Ciência Agronômica, v.41, p.442-447, 2010. http://dx.doi. org/10.1590/S1806-66902010000300017 